\title{
Correction to: Predict cognitive decline with clinical markers in Parkinson's disease (PRECODE-1)
}

\author{
Heather Wilson ${ }^{1}$ (i) $\cdot$ Gennaro Pagano ${ }^{1} \cdot$ Tayyabah Yousaf $^{1} \cdot$ Sotirios Polychronis $^{1} \cdot$ Rosa De Micco $^{1}$. \\ Beniamino Giordano ${ }^{1} \cdot$ Flavia Niccolini $^{1} \cdot$ Marios Politis $^{1}$
}

Published online: 1 March 2022

(c) The Author(s) 2022

\section{Correction to: \\ Journal of Neural Transmission (2020) 127:51-59 https://doi.org/10.1007/s00702-019-02125-6}

The original version of this article unfortunately contained a mistake. The following article note is missing. Gennaro Pagano is joint first author with Heather Wilson.

Open Access This article is licensed under a Creative Commons Attribution 4.0 International License, which permits use, sharing, adaptation, distribution and reproduction in any medium or format, as long as you give appropriate credit to the original author(s) and the source, provide a link to the Creative Commons licence, and indicate if changes were made. The images or other third party material in this article are included in the article's Creative Commons licence, unless indicated otherwise in a credit line to the material. If material is not included in the article's Creative Commons licence and your intended use is not permitted by statutory regulation or exceeds the permitted use, you will need to obtain permission directly from the copyright holder. To view a copy of this licence, visit http://creativecommons.org/licenses/by/4.0/.

Publisher's Note Springer Nature remains neutral with regard to jurisdictional claims in published maps and institutional affiliations.
The original article can be found online at https://doi.org/10.1007/ s00702-019-02125-6.

\section{Marios Politis}

mariospolitis@gmail.com

1 Neurodegeneration Imaging Group, Maurice Wohl Clinical Neuroscience Institute, Institute of Psychiatry, Psychology and Neuroscience (IoPPN), King's College London, 125 Coldharbour Lane, Camberwell, London SE5 9NU, UK 